\title{
THE EFFECT OF MYCORRHIZAL (GLOMUS INTRARADICES) COLONIZATION ON THE DEVELOPMENT OF ROOT AND STEM ROT (PHYTOPHTHORA VIGNAE) OF COWPEA
}

\author{
W.G.D. FERNANDO ${ }^{1}$ and R.G. LINDERMAN ${ }^{2 *}$ \\ ${ }^{1}$ Department of Botany and Plant Pathology, Oregon State University, Corvallis, \\ OR 97331-2902, USA. \\ ${ }^{2}$ USDA-ARS Horticultural Crops Research Laboratory, 3420NW Orchard Ave., Corvallis, \\ OR 97330, USA.
}

(Received: 07 December 1995; accepted: 01 November 1996)

\begin{abstract}
The effect of prior colonization of cowpea roots by the vesiculararbuscular mycorrhizal (VAM) fungus, Glomus intraradices, on the detrimental effects on plant growth induced by the stem and root rot pathogen Phytophthora vignae was evaluated. VAM and non-VAM plants, inoculated by transplanting into soil with $0.1,0.5$, or $1.0 \%$ pathogen inoculum/soil $(\mathrm{v} / \mathrm{v})$, were evaluated for effects upon disease incidence after 2 wks of further growth. There were no shoot or root growth differences between VAM and non-VAM plants in the absence of the pathogen, because all plants were fertilized sufficiently. Reduction of shoot growth due to the disease was less on VAM plants, at the lowest $(0.1 \%)$ pathogen inoculum level. Mycorrhizal colonization had no significant effect on root weight at any pathogen inoculum level. Stem and root disease severity were significantly lower only at $1.0 \%$ inoculum level, whereas percent root infection was lower at the 0.5 and $1.0 \%$ inoculum levels. Root colonization by the VAM fungus was reduced proportional to the pathogen inoculum level and amount of root infection. These results indicate that inoculation with $G$. intraradices could provide some degree of reduction of $P$. vignae stem and root rot disease on cowpeas, independent of nutritional or other growth effects.
\end{abstract}

Key words: Biological control, Glomus intraradices, mycorrhizae, Phytophthora vignae, Vigna unguiculata.

\section{INTRODUCTION}

The symbiotic relationship between roots of higher plants and specialized soil fungi, known as mycorrhizae, is predominantly vesicular-arbuscular mycorrhizae on most agricultural crops. Vesicular-arbuscular mycorrhizal (VAM) fungi are a major component of plant rhizospheres and these interact with other soil microbes like bacteria, fungi, and nematodes. ${ }^{1}$ The presence of VAM causes plant physiological changes and the soil around mycorrhizae has been called the mycorrhizosphere. ${ }^{2}$ Microbial interactions in the mycorrhizosphere may significantly influence plant growth and health.

Several reviews have been published on the interactions of VAM fungi with soilborne root pathogens, especially fungi. ${ }^{3-5}$ Some reports indicate that

\footnotetext{
" Corresponding author
} 
mycorrhizae reduce root disease, ${ }^{6}$ while others suggest that they may increase disease. ${ }^{7}$ The interaction of the host, pathogen, and VAM fungi in specific soils determines the outcome of these observations. Furthermore, the methods and approaches in studies differ, and those differences may have influenced the results observed. ${ }^{8.9}$

In many parts of the world, cowpeas (Vigna unguiculata sub sp. unguiculata Walp. L.) are severely affected by the stem and root rot pathogen Phytophthora vignae Purss. Purss ${ }^{10}$ reported and characterized the fungus for the first time. Sivakadadcham \& Fernando ${ }^{11}$ reported the presence of the pathogen in Sri Lanka. Fernando \& Linderman ${ }^{12}$ further described the occurrence, distribution and pathogenicity of the fungus in soils of Sri Lanka.

The disease is characterized by shrinking of the basal stem at or near the soil surface resulting in permanent wilting and death of the plant. ${ }^{13}$ Control of the disease is largely by the use of resistant varieties, but in many areas those varieties are not grown. Fungicides such as metalaxyl could be very effective in control, ${ }^{14}$ but fungicide resistant strains could develop with the continuous use of the same fungicide. ${ }^{15}$ Furthermore, the use of fungicides is prohibitively expensive.

Therefore, there is need to find alternative control measures. We recently reported on the use of bacterial antagonists to control this disease ${ }^{16}$ and an integrated control procedure, with the use of a chemical fungicide and a biocontrol agent in combination. ${ }^{14}$ Most tropical soils are inhabited by mycorrhizal fungi that are good colonizers of legumes such as cowpeas. ${ }^{17}$ Their presence could have a marked effect on pathogenesis and severity of a root disease. Phytophthora vignae was present in some soils in Sri Lanka, but did not cause symptoms on susceptible cultivars grown in the region. ${ }^{12}$ This could be due to the presence of antagonistic microorganisms. ${ }^{18}$ Mycorrhizal fungi could contribute significantly to this. ${ }^{5}$

Our objective was to investigate the effect of a common mycorrhizal fungus in tropical soils, that could have a significant impact on control of $P$. vignae. Here we report the results of the potential effect of the VAM fungus Glomus intraradices on the incidence and severity of Phytophthora stem and root rot of cowpea.

\section{METHODS AND MATERIALS}

Preparation of soil and plant material: The experiments were carried out at the Horticultural Crops Research Laboratory, United States Department of Agriculture, Agriculture Research Service in Corvallis, Oregon. Experiments were conducted on greenhouse benches with a $16 \mathrm{~h}$ photo period of $240 \mu \mathrm{Em}^{-2} \mathrm{~S}^{-1}$ from high pressure sodium vapor lamps, at $26^{\circ} \mathrm{C}$ day and $20^{\circ} \mathrm{C}$ night temperatures. 
A steam pasteurized (air-steam $60^{\circ} \mathrm{C} / 30 \mathrm{~min}$ ) $1: 1$ mixture of sandy loam soil $(\mathrm{pH}=6)$ and river sand was used in $12 \times 12 \mathrm{~cm}$ round pots in all experiments. There were 40 pots per treatment. Seeds of a highly susceptible cowpea, Vigna unguiculata (L.) Walp. sub sp. unguiculata var. California Blackeye purchased from Park Seed Co.(Greenwood, South Carolina, USA), were used in all experiments. Glomus intraradices Schenck and Smith (purchased from NPI, Salt Lake City, Utah) was used as VAM fungal inoculum. The concentration of spores in the inoculum, determined by wet sieving and counting under a dissecting microscope at $30 \mathrm{x}$, was 750 spores $\mathrm{g}^{-1}$ soil, and $26.6 \mathrm{~g}$ of inoculum was mixed thoroughly by hand into $1 \mathrm{~kg}$ of soil mix prior to seeding. Others were left noninoculated (-VAM). Plants were fertilized weekly with $10 \mathrm{ml} /$ pot of Long Ashton Nutrient Solution ${ }^{19}$ with $\mathrm{P}$ at $44 \mathrm{mg} / \mathrm{L}(1.5 \mathrm{mM}$ of $\mathrm{P})$, starting on the 14 th day. Only one level of $\mathrm{P}$ was used, as Ames and Bethlenfalvay ${ }^{20}$ reported that there was no significant growth enhancement effect of treatment with different $P$ levels with cowpea var. California Blackeye. The plants were watered every other day.

Inoculation of plants by P. vignae: Phytophthora vignae (isolate P001) was grown at room temperature for 7 days on Potato Dextrose Agar (PDA) [Difco] amended with $2 \%$ pimaricin. Ten $0.7 \mathrm{~mm}$ diameter plugs were cut with a cork borer from the actively growing margin and inoculated into sterilized medium in flasks comprised of $500 \mathrm{ml}$ of coarse vermiculite $+300 \mathrm{ml} \mathrm{V8}$ solution $[200 \mathrm{ml}$ V8 concentrate, $800 \mathrm{ml}$ distilled water $+2 \mathrm{~g} \mathrm{CaCO}_{3}$ ]. The inoculum was grown for one month at room temperature $\left(23^{\circ} \mathrm{C}\right)$ in the dark to form mycelium and oospores.

Plants inoculated with $G$. intraradices at the time of seeding were removed gently after 30 days, and the soil was uniformly amended with $0,0.1,0.5$ and $1.0 \% \mathrm{v} / \mathrm{v}$ of $P$. vignae inoculum. These rates were determined in other experiments to give low, moderate, and high levels of infection. ${ }^{16}$ The plants were allowed to grow further, under the conditions described above, for two more weeks. This period was relatively short, but was chosen on the basis of previous tests to be the time needed for definitive disease symptoms to occur. ${ }^{16}$ The experimental design was a completely randomized design with 10 replicate pots per treatment. The experiment was repeated once.

Evaluation of VAM colonization, pathogen infection, and disease severity: At harvest, roots were removed from the soil, stem and leaves, and roots were dried for $72 \mathrm{~h}$ at $65^{\circ} \mathrm{C}$ and weighed separately to determine stem and root dry weights. At the same time roots from all treatment replicates were removed from soil, thoroughly washed and cut into approximately $1 \mathrm{~cm}$ lengths, and $1 \mathrm{~g}$ (fresh weight) were cleared and stained for VAM fungal colonization according to the methods of Phillips \& Hayman. ${ }^{21}$ The line intersect method was used to determine the percent of root pieces with signs of VAM fungal colonization. 
Twenty remaining root pieces, per treatment (randomly chosen across the $10 \mathrm{reps} / \mathrm{tmt}$ ) were surface sterilized by dipping into $70 \%$ ethanol for $2 \mathrm{~min}$, then drying on sterile paper towels. Ten root pieces were placed on each of two Petri plates containing Corn Meal Agar (CMA) prepared with 200 ppm Pimaricin, 100 ppm Ampicillin, 10 ppm Rifampicin, 100 ppm Pentachloronitrobenzene (PCNB), and 20 ppm Hymexazol per liter (PARPH in CMA) to control bacteria and fungi other than $P$. vignae. The plates were incubated for four days at room temperature to allow $P$. vignae colonies to grow onto the medium. Percent root pieces infected was determined.

Disease severity index (DSI) was determined separately for stem and roots at harvest using a 0-5 scale for stems, where $0=$ healthy, $1=$ leaves pale green and/or stem lesions at base, $2=$ leaves wilted and/or dry and leaves drooping while stem lesion advanced upwards, $3=$ symptoms of level 2 with lesion over $2 \mathrm{~cm}$ and/or girdling at base, $4=70-90 \%$ of plant diseased, $5=$ plant dead.

Root DSI ratings were on a scale of $0-4$, where $0=$ healthy, $1=<25 \%$ of lateral roots with lesions, but no tap root necrosis, $2=25-50 \%$ of roots necrotic, and $<50 \%$ tap root necrosis, $3=25-50 \%$ of root necrosis and $>50 \%$ of tap root necrotic, $4=>75 \%$ lateral + tap root necrosis.

Data analysis: Data were analysed by one way analysis of variance. Means were separated using Waller-Duncan Baysian K-ratio test at $\mathrm{p}<0.01$ ( $\mathrm{K}=100$ level) ${ }^{22}$ As the treatments consisted of different quantitative levels of pathogen inoculum, data were also analysed by polynomial regression and log linear analysis, but this did not add information to the ANOVA. The results are best represented by ANOVA.

\section{RESULTS}

Inoculation with the VAM fungus in the absence of $P$. vignae bad no significant effect on plant growth (Table 1). The reduction of shoot dry weight (SDW) due to inoculation of cowpea with $P$. vignae was less on VAM than non-VAM plants, only at the lowest pathogen inoculum level $(0.1 \% \mathrm{v} / \mathrm{v})$. The SDW of non-VAM and VAM plants inoculated with $1.0 \%$ pathogen inoculum were significantly lower than plants inoculated at other inoculum levels. Only VAM plants showed a significant difference between 0.1 and $0.5 \%$ inoculum levels. At each pathogen inoculum level, root dry weights (RDW) of VAM and non-VAM plants were not significantly different from each other (Table 1). However, the root dry weight of VAM plants inoculated with $P$. vignae $(1.0 \%)$ or without $(0.0 \%)$ were significantly different from each other. 
18. Linderman R.G., Moore L.W., Baker K.F., \& Cooksey D. A. (1983). Strategies for detecting and characterizing systems for biological control of soilborne pathogens. Plant Disease 67: 1058-1064.

19. Hewitt E.J. (1966). Sand and water culture methods used in the study of plant nutrition. (Technical Communication no. 22) 2nd ed. Commonwealth Agricultural Bureau, London.

20. Ames R.N., \& Bethlenfalvay G.J. (1987). Localized increase in nodule activity but no competitive interaction of cowpea rhizobia due to pre-establishment of vesicular-arbuscular mycorrhiza. New Phytologist 106: 207-215.

21. Phillips J.M. \& Hayman D.S. (1970). Improved procedure for clearing roots and staining parasitic and vesicular-arbuscular mycorrhizal fungi for rapid assessment of infection. Transactions of the British Mycological Society 55: 158-161.

22. Waller R.A. \& Duncan D.B. (1969). A Bayes rule for the symmetric multiple comparison problem. Journal of the American Statistics Association 64: $1484-1503$.

23. Graham J.H.\& Menge J.A. (1982). Influence of vesicular-arbuscular mycorrhiza and soil phosphorus on take-all disease of wheat. Phytopathology 72: 95-98.

24. Morandi D., Bailey J.A. \& Gianinazzi-Pearson V. (1984). Isoflavonoid accumulation in soybean roots infected with vesicular-arbuscular mycorrhizal fungi. Physiological Plant Pathology 24: 357-364.

25. Afek U., \& Menge J.A. (1990). Effect of Pythium ultimum and metalaxyl treatments on root length and mycorrhizal colonization of cotton, onion, and pepper. Plant Disease 74: 117-120.

26. Meyer J.R. \& Linderman R.G. (1986). Selective influence on populations of rhizosphere or rhizoplane bacteria and actinomycetes by mycorrhizas formed by Glomus fasciculatum. Soil Biology and Biochemistry 18: 191-196.

27. Linderman R.G. \& Paulitz T.C. (1990). Mycorrhizal-rhizobacterial interactions. In: Biological control of soil-borne plant pathogens. (Ed. D. Hornby et al.) pp. 261-283. CAB International, Great Britain. 